\title{
КОНСТЕЛЯЦІЯ БІОХІМІЧНИХ ТА ФІЗИЧНИХ МАРКЕРІВ ФУНКЦІОНАЛЬНОГО СТАНУ ОРГАНІЗМУ ХВОРИХ НА ІНФАРКТ МІОКАРДА 3 РІВНЯМИ СИСТОЛІЧНОГО І ДІАСТОЛІЧНОГО АРТЕРІАЛЬНОГО ТИСКУ ТА МОЖЛИВІСТЬ ЇХ ВИКОРИСТАННЯ У ПРОЦЕСІ РЕАБІЛІТАЦІЇ
}

Вступ. Надання повноцінної медичної допомоги хворим на інфраркт міокарда (IM) з коморбідною патологією (КП) на фроні артеріальної гіпертензії залишається складною медичною проблемою, якої на сьогодні не вирішено.

Мета дослідження - вивчити особливості клінічного перебігу інфраркту міокарда з коморбідною патологією залежно від рівнів систолічного та діастолічного артеріального тиску, виявити ранні маркерні й лімітуючі параметри фрункціональних показників організму і стратифрікаційні ризики для контролю за ефрективністю реабілітаційного процесу в цієї категорії пацієнтів.

Методи дослідження. Обстежено 371 хворого на інфраркт міокарда віком $(66,2 \pm 10,4)$ року. В 93,8 \% обстежених було виявлено супутню патологію. Вивчено основні фрункціональні показники стану організму хворого на ІМ з КП та їх зв'язок із систолічним (САТ) і діастолічним артеріальним тиском (ДАТ), а також з показниками толерантності до фрізичного навантаження.

Результати й обговорення. Було встановлено пряму кореляцію між рівнями САТ у гострий період IM та тривалістю анамнезу артеріальної гіпертензії ( $r=0,130 ; P=0,040)$, товщиною задньої стінки лівого шлуночка ( $r=0,189$; $P<0,001)$, фрракцією викиду лівого шлуночка $(r=0,275 ; P<0,0001)$ і розміром аорти $(r=0,228$; $P<0,0001)$. Існував також достовірний прямий зв'язок між рівнями ДАТ і товщиною задньої стінки лівого шлуночка ( $r=0,130 ; P=0,022)$, розміром аорти $(r=0,172 ; P=0,002)$, розміром лівого передсердя $(r=0,188$; $P=0,001)$, фрракцією викиду лівого шлуночка $(r=0,210 ; P<0,001)$, а також рівнем креатиніну крові $(r=0,119$; $P=0,023)$. Виявлений достовірний обернений зв'язок між рівнями САТ/ДАТ і пароксизмом фрібриляції передсердь, кардіогенним шоком, набряком легень та аневризмою лівого шлуночка може свідчити про виснаження гемодинамічних резервів, знижених внаслідок гострого ішемічного ушкодження міокарда.

Висновки. Показники САТ/ДАТ у гострий період IM є ранніми прогностичними маркерами біохімічних, морфологічних та гемодинамічних змін у хворих на IM з КП, адекватно відображають загальний фрункціональний стан пацієнта і серцево-судинні ризики, тому їх необхідно моніторувати в процесі реабілітації. Існує достовірний прямий зв'язок рівня креатиніну в таких пацієнтів з показниками ДАТ у гострий період IM та морфологічними змінами серцевого м'яза, тому його можна успішно використовувати як маркер системного гемодинамічного контролю на етапах кардіореабілітації.

КЛЮЧОВІ СЛОВА: інфраркт міокарда; коморбідна патологія; артеріальна гіпертензія; кардіореабілітація.

ВСТУП. Хвороби системи кровообігу залишаються протягом багатьох років основною причиною смертності населення України, причому найбільш поширена артеріальна гіпертензія (АГ), вона ж є і однією з головних причин розвитку фратальних та нефатальних ускладнень при гострому інфраркті міокарда (IM) [1-4]. Використання новітніх технологій у лікуванні гострих коронарних синдромів значно знизило рівень летальності та покращило серцево-судинний прогноз. Однак надання повноцінної медичної (с Л. В. Левицька, 2019. допомоги хворим на IM з коморбідною патологією (КП) на фоні артеріальної гіпертензії залишається складною медичною проблемою, якої на сьогодні не вирішено $[5,6]$.

Мета дослідження - вивчити особливості клінічного перебігу інфраркту міокарда з коморбідною патологією залежно від рівнів систолічного та діастолічного артеріального тиску, виявити ранні маркерні й лімітуючі параметри функціональних показників організму і стратифрікаційні ризики для контролю за ефективністю реабілітаційного процесу в цієї категорії пацієнтів. 
МЕТОДИДОСЛІДЖЕННЯ. Обстежено 371 Хворого на інфраркт міокарда, які проходили гострий період реабілітації в кардіологічному відділенні Тернопільської університетської лікарні й були послідовно включені до місцевого реєстру. Діагноз встановлювали відповідно до діючих протоколів лікування та реабілітації [7-9]. Критеріями залучення пацієнтів у дослідження були підтверджений діагноз IM та письмова інсрормована їх згода на участь у дослідженні, критеріями незалучення - гострі інфеекційні й психічні захворювання, декомпенсація супутньої патології, наявність гемодинамічно значущих вад серця і проведення хірургічної реваскуляризації інсрарктозалежної судини. Для оцінки ступеня коморбідності у хворих на IM із супутньою патологією використано індекс коморбідності Чарльсона [10]. Морфометричні параметри внутрішньосерцевої гемодинаміки оцінювали ехокардіоскопічним методом на апараті "Philips HD11XE” (США) згідно з рекомендаціями щодо ультразвукового дослідження серця Американського товариства з ехокардіографрії та Європейської асоціації 3 ехокардіограсрії (ASE/EAS 2015). Електрокардіограми реєстрували за допомогою ЕКГ-апарата "ЮТАС". Лабораторні дослідження проводили за стандартними методиками. Вони включали загальний аналіз крові, коагулограму, біохімічне дослідження крові (глюкоза, білірубін, трансамінази, креатинін, сечовина, сечова кислота, показники ліпідного спектра плазми крові: загальний холестерол, триацилгліцероли, ліпопротеїни високої і низької щільності).

Функціональні резерви серцево-судинної системи та ступінь ризику серцево-судинних подій (ССП) визначали методом бальної оцінки окремих її параметрів: при величині фрракції викиду (ФВ) лівого шлуночка (ЛШ) понад 55 \% 1 бал, 45-55 \% - 2 бали, 30-45 \% - 3 бали і менше $30 \%$ - 4 бали. Таким же чином оцінювали серцеву недостатність (CH) за NYHA: I фрункціональний клас (ФК) - 1 бал, II ФК - 2 бали, III ФК - 3 бали i IV ФК - 4 бали та статус ризику ССП за реабілітаційною класифрікацією (Л. Ф. Ніколаєва і співавт.): I ФК - 1 бал, II ФК - 2 бали, III ФК - 3 бали і IV ФК - 4 бали. За шкалою GRACE та шкалою ризику серцево-судинних подій (АНА) післяінфарктних хворих поділяли на групи малого, середнього і високого ризику з відповідним присвоєнням 1, 2 та 3-х балів [11]. Тест шестихвилинної ходьби (ТШХ) [12] проводили та оцінювали на 10-й, 30-й та 90-й дні після госпіталізації хворого в клініку.

Статистичний аналіз проводили за допомогою програмних продуктів MS Excel 2000 i EViews 5.1. Для кількісних змінних обчислено середні значення і стандартні відхилення, для категорій- них - абсолютну кількість та відсоткові частки для кожної категорії. Для кількісних змінних досліджували статистичну значущість відмінностей між групами пацієнтів із супутньою патологією та без неї за допомогою t-критерію Стьюдента для незалежних вибірок. Аналіз порівнянності розподілів якісних (категорійних) ознак у групах проводили з використанням критерію $\chi^{2}$ (категорійні змінні представлено як абсолютну кількість для кожної категорії). При аналізі взаємозв'язків між кількісними показниками обчислювали стандартний коефріцієнт кореляції Пірсона, між кількісними і категорійними (2 категорії) - точково-бісерійний коефріцієнт кореляції, між кількісними та категорійними (понад 2 категорії) - проводили дисперсійний аналіз (ANOVA) і визначали коефріцієнт $\eta^{2}$ (ета-квадрат), між двома категорійними показниками - коефіцієнт асоціації Юла (підтвердженим вважали зв'язок, коли коесріцієнт асоціації за модулем перевищував 0,5). Використовуючи всі інші статистичні критерії і засоби аналізу, за статистично значущі брали відмінності та зв'язки при значенні $\mathrm{P}<0,05[13,14]$.

РЕЗУЛЬТАТИ Й ОБГОВОРЕННЯ. За ДаНИМИ дослідження, обстежені хворі на IM були віком $(66,2 \pm 10,4)$ року. Час від появи перших симптомів захворювання до моменту госпіталізації в них становив у середньому $(20,3 \pm 15,1)$ год. Серед усіх пацієнтів було $249(67,12 \%)$ чоловіків і 122 $(32,88$ \%) жінки; 73 (19,7 \%) хворих були жителями міста, 298 (80,3 \%) - жителями села. У більшості обстежених (93,8 \%) виявлено супутню патологію.

Враховуючи те, що параметри систолічного (САТ) і діастолічного артеріального тиску (ДАТ) у Хворих на IM $€$ простими для вимірювання та контролю, але водночас достатньо інфрормативними інтегральними показниками їх фрункціонального стану, ми більш детально проаналізували можливі взаємозв'язки між САТ і ДАТ та фрункціональними показниками життєдіяльності в цієї категорії пацієнтів (табл. 1).

У результаті проведеного аналізу взаємозв'язків САТ і ДАТ із числовими фрункціональними показниками було встановлено, що рівні САТ перебували у прямій кореляції з тривалістю анамнезу АГ, товщиною задньої стінки ЛШ, срракцією викиду ЛШ та розміром аорти і в оберненій залежності з ЧСС та кількістю лейкоцитів у перисреричній крові. Цифрри ДАТ також позитивно корелювали з товщиною задньої стінки лШ, фрракцією викиду ЛШ, розміром аорти, розміром лівого передсердя і рівнем креатиніну крові та в оберненій залежності з ЧСС, рівнями глікемії і кількістю лейкоцитів. Важливим було виявлення тісного оберненого кореляційного 
Таблиця 1 - Залежність основних функціональних кількісних показників у хворих на інфаркт міокарда з коморбідною патологією від рівнів артеріального тиску в гострий період

\begin{tabular}{|l|c|c|c|c|c|c|}
\hline \multirow{2}{*}{ Показник } & \multicolumn{3}{|c|}{ Для САТ } & \multicolumn{3}{c|}{ Для ДАТ } \\
\cline { 2 - 7 } & кореляція & Т-критерій & Р-значення & кореляція & Т-критерій & Р-значення \\
\hline $\begin{array}{l}\text { Тривалість анамнезу АГ, } \\
\text { роки }\end{array}$ & 0,130 & 2,068 & 0,040 & 0,103 & 1,626 & 0,105 \\
\hline ЧСС у гострий період ІМ & $-0,178$ & $-3,472$ & $<0,001$ & $-0,136$ & $-2,629$ & $<0,001$ \\
\hline ЧдР, дихальні рухи/хв & $-0,052$ & $-0,994$ & 0,321 & $-0,012$ & $-0,235$ & 0,814 \\
\hline Кількість лейкоцитів, ×109 & $-0,152$ & $-2,943$ & 0,003 & $-0,152$ & $-2,934$ & 0,004 \\
\hline Лімооцити, \% & 0,062 & 1,186 & 0,237 & 0,068 & 1,295 & 0,196 \\
\hline Глюкоза, ммоль/л & $-0,156$ & $-2,980$ & 0,003 & $-0,095$ & $-1,807$ & 0,072 \\
\hline Креатинін, ммоль/л & $-0,071$ & $-1,360$ & 0,175 & 0,119 & 2,290 & 0,023 \\
\hline Тропонін Т, нг/мл & $-0,071$ & $-1,197$ & 0,232 & $-0,058$ & $-0,978$ & 0,329 \\
\hline Розмір аорти, см & 0,228 & 4,134 & $<0,0001$ & 0,172 & 3,084 & 0,002 \\
\hline $\begin{array}{l}\text { Розмір лівого передсердя, } \\
\text { см }\end{array}$ & $-0,104$ & $-1,806$ & 0,072 & 0,188 & 3,304 & 0,001 \\
\hline $\begin{array}{l}\text { Кінцевий діастолічний } \\
\text { розмір лівого шлуночка, } \\
\text { см }\end{array}$ & $-0,095$ & $-1,642$ & 0,102 & $-0,139$ & $-2,431$ & 0,016 \\
\hline $\begin{array}{l}\text { Товщина міжшлуночкової } \\
\text { перегородки, см }\end{array}$ & 0,077 & 1,348 & 0,179 & 0,083 & 1,463 & 0,144 \\
\hline $\begin{array}{l}\text { Товщина задньої стінки } \\
\text { лівого шлуночка, см }\end{array}$ & 0,189 & 3,366 & $<0,001$ & 0,130 & 2,301 & 0,022 \\
\hline $\begin{array}{l}\text { Фракція викиду лівого } \\
\text { шлуночка, \% }\end{array}$ & 0,275 & 5,074 & $<0,0001$ & 0,210 & 3,811 & $<0,001$ \\
\hline Т-ргоВлР & $-0,077$ & $-0,549$ & 0,586 & $-0,182$ & $-1,319$ & 0,193 \\
\hline $\begin{array}{l}\text { Активна посадка в ліжку, } \\
\text { день }\end{array}$ & $-0,168$ & $-1,849$ & 0,067 & $-0,168$ & $-1,849$ & 0,067 \\
\hline Ходьба 10 м, день & $-0,019$ & $-0,207$ & 0,836 & $-0,023$ & $-0,249$ & 0,804 \\
\hline Ходьба 100 м, день & 0,122 & 1,010 & 0,316 & 0,198 & 1,664 & 0,101 \\
\hline \hline
\end{tabular}

Примітка. ЧСС - частота серцевих скорочень; ЧДР - частота дихальних рухів; NT-proBNP - мозковий натрійуретичний пептид.

зв'язку між рівнями діастолічного артеріального тиску і кінцевим діастолічним розміром Лш. Тобто, незважаючи на те, що між рівнями систолічного та діастолічного артеріального тиску існує достовірний сильний прямий кореляційний зв'язок і вони однонаправлено залежать від основних показників внутрішньосерцевої гемодинаміки та супутніх змін геометрії лівого шлуночка й аорти, саме показники діастолічного артеріального тиску мають переважний вплив не лише на розвиток діастолічної дисорункції, але й на системні зміни морфології серцевого м'яза і порушення орункції нирок.

Дані нашого дослідження, що стосуються виявлення кореляційного зв'язку між рівнями діастолічного тиску і рівнем креатиніну крові, збігаються з результатами, які отримали інші дослідники [15-17], і вказують на те, що рівні саме діастолічного артеріального тиску пов'язані перш за все з розвитком порушення функції нирок. Тому рівень креатиніну сироватки крові та швидкість клубочкової фрільтрації за кліренсом креатиніну можна успішно використовувати як маркери контролю в процесі проведення кардіореабілітації.
Що стосується ранніх маркерів адекватності реабілітації хворих на ІМ, таких, як день активної посадки в ліжку, день, коли пацієнт освоїв ходьбу на 10 і 100 м, то було встановлено лише тенденцію оберненого кореляційного зв'язку за днем активної посадки пацієнта в ліжку як із рівнями САТ, так і з рівнями ДАТ. Очевидно, ранні реабілітаційні заходи в пацієнтів з гіпертензією слід проводити 3 меншою динамікою фрізичної активації, ніж у хворих з нормальними рівнями АТ. Проте більш чіткі рекомендації можна сорормулювати після поглибленого вивчення взаємозв'язків цих та інших маркерів реабілітаційного процесу з функціональними показниками хворих на IM на етапах реабілітації.

При вивченні залежності рівнів АТ у гострий період ІМ від наявності чи відсутності, а також характеру супутньої патології (табл. 2) було встановлено достовірну пряму кореляцію як САТ, так і ДАТ із наявністю судинної патології (церебральної і нецеребральної локалізації), артеріальної гіпертензії та діастолічної дисфункції (табл. 3). Отримані результати виявилися логічними й очікуваними, аналогічні дані одержували в багатьох подібних дослідженнях [18-20]. Вочевидь, тривалий системний атеросклеротич- 

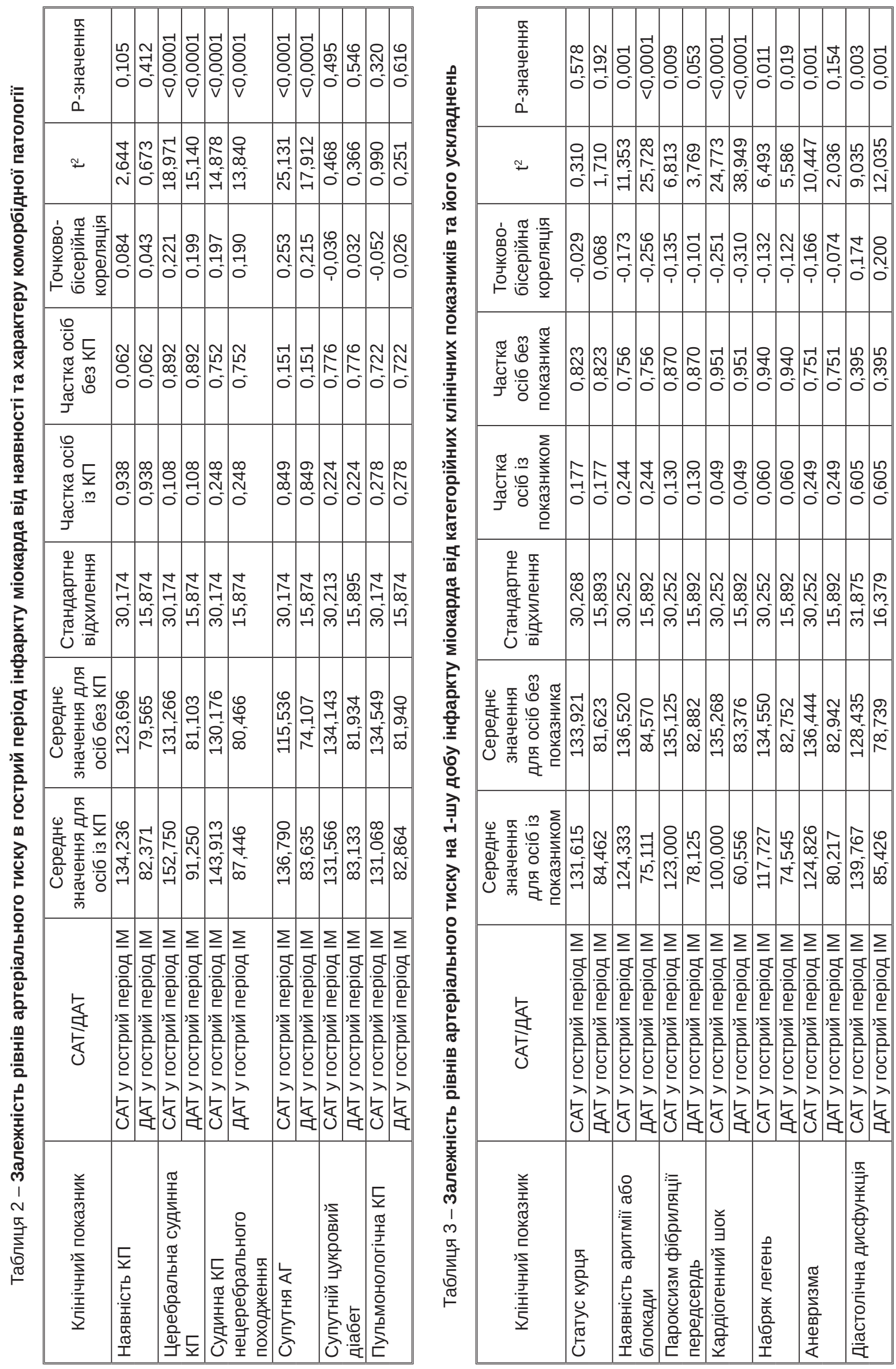

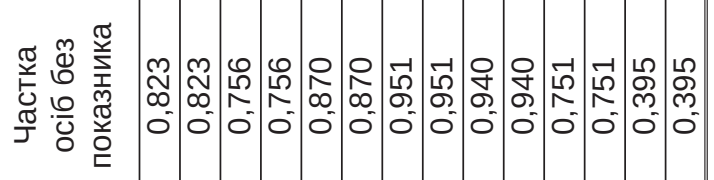

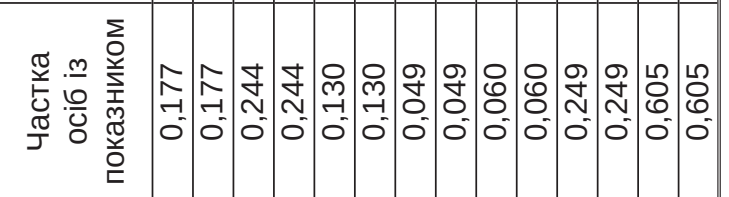

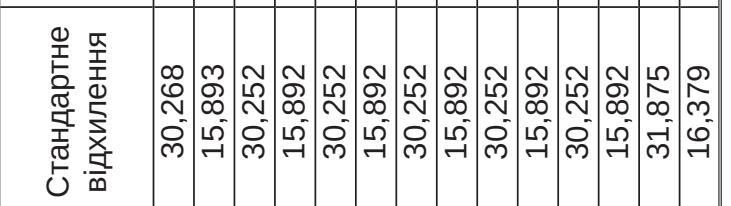

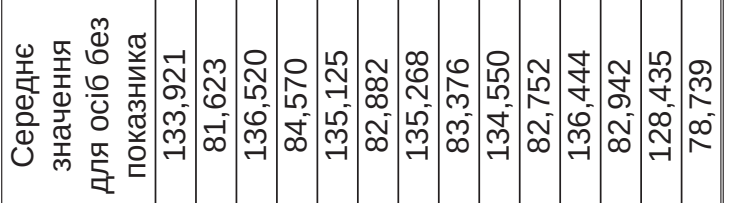

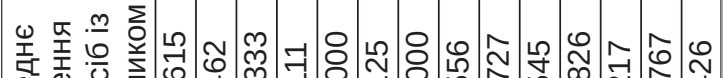

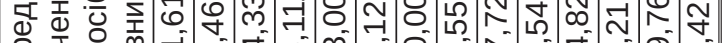
U

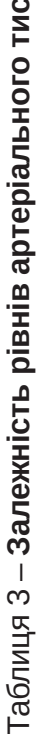

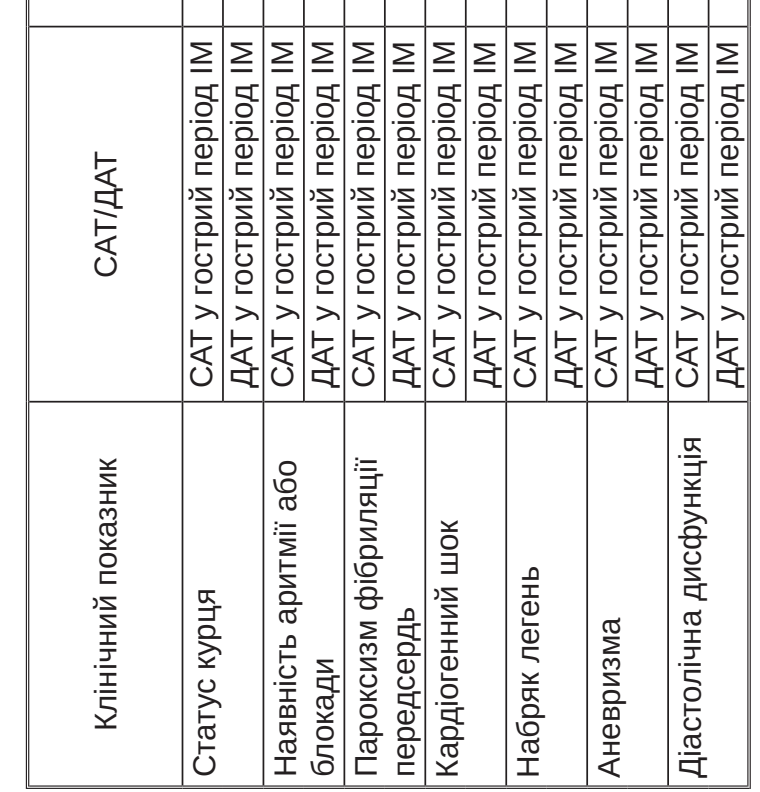


ний процес, який маніфестував клінічними формами церебральної та периферичної судинної патології на фоні тривалої АГ, у перші години розвитку гострого коронарного синдрому проявляється високими рівнями САТ і ДАТ. При супутніх цукровому діабеті, пульмонологічній патології та в цілому за наявності чи відсутності коморбідної патології у хворих на IM такої залежності не було виявлено.

Виявлений у процесі аналізу достовірний обернений зв'язок між рівнями САТ і такими ускладненнями IM, як порушення ритму та провідності, в тому числі пароксизм фрібриляції передсердь, кардіогенний шок, набряк легень та аневризма ЛШ (табл. 3), може свідчити про виснаження гемодинамічних резервів компенсації зниженої внаслідок гострого ішемічного ушкодження насосної фрункції міокарда. Кореляція між рівнями ДАТ і порушеннями ритму та провідності, в тому числі пароксизмом фрібриляції передсердь, кардіогенним шоком та набряком легень, також була оберненою і достовірною.

Отже, проведене дослідження дозволило зробити висновок, що динаміка показників систолічного і діастолічного артеріального тиску в гострий період інсаркту міокарда може бути не лише простим та надійним маркером змін, які відбуваються в порушеній патологічним процесом гемодинамічній системі, але і предиктором розвитку ускладнень. Оскільки рівні САТ і ДАТ у гострий період IM прямо пов'язані з геометрією порожнин серця, розміром аорти та їх фрункціональним станом (фрракцією викиду ЛШ), а також перебувають в оберненій залежності з ЧСС, саме ці показники необхідно першочергово контролювати в процесі реабілітації пацієнтів з гіпертензією. Низькі рівні систолічного та діастолічного артеріального тиску в гострий період IM свідчать про виснаження гемодинамічного ресурсного забезпечення компенсації різкого зниження систолічної фрункції серцевого м'яза, і їх можна розглядати як лімітуючі маркери для проведення ранньої активації пацієнтів.

Отримані дані підтвердили результати невеликої кількості досліджень останніх років про те, що як надмірно високий, так і занадто низький артеріальний тиск може бути пов'язаний з поганим прогнозом у пацієнтів з ішемічною хворобою серця - так званий френомен “Ј-кривої" [19-21]. Дослідження, під час яких вивчали зв'язок рівнів АТ з ризиками та прогнозом у хворих на ішемічну хворобу серця, в цілому підтвердили важливість утримання САТ і ДАТ у межах цільових рівнів протягом тривалого періоду спостереження. Однак ретельний літературний пошук виявив лише одиничні роботи, автори яких оцінювали вихідні параметри АТ у пацієнтів з IM як предиктори серцево-судинних подій. У цьому аспекті показовим $є$ дослідження австрійських учених [20], які вивчали рівні систолічного, діастолічного та пульсового тиску як предиктори серцево-судинної смертності на когорті послідовно включених у дослідження з 1991 до 2009 р. 3943 хворих на IM. Було встановлено, що з підвищенням рівнів артеріального тиску при госпіталізації у відділення невідкладної медичної допомоги однорічний ризик смертності зменшувався до $70 \%$, знижуючи відносний ризик у категоріях вищого артеріального тиску порівняно з найнижчими категоріями. Цей ефеек не залежав від втручань, які змінюють кров'яний тиск. Учені зробили висновок, що при гострому інфаркті міокарда артеріальний тиск $є$ предиктором довгострокової смертності у зворотному порядку: зі збільшенням рівнів АТ при госпіталізації у відділення невідкладної медичної допомоги віддалена летальність зменшується. Натомість низький АТ при госпіталізації асоційований з гіршим довгостроковим прогнозом і повинен слугувати попереджувальним знаком у пацієнтів з IM.

Ґрунтовна робота J. P. Ferreira та співавт. [21], які проаналізували дані 28771 пацієнта, отримані після проведення чотирьох досліджень (CAPRICORN, EPHESUS, OPTIMAAL I VALIANT), також була присвячена вивченню впливу рівнів середнього офрісного АТ протягом усього періоду спостереження на показники серцево-судинної смертності та ризику виникнення повторних серцево-судинних подій. Результати цього дослідження в популяції пацієнтів з IM, ускладненим систолічною диссрункцією або вираженою серцевою недостатністю, показали, що асоціація 3 несприятливим прогнозом стрімко зростає 3 рівнями АТ $<125 / 75$ мм рт. ст. Натомість виникнення інсульту в таких хворих асоціюється 3 AT >140 мм рт. ст.

Дослідження M. Sola та співавт. [22], які вивчали співвідношення рівнів систолічного артеріального тиску до рівнів кінцевого діастолічного тиску лівого шлуночка (ДТЛШ) під час первинного черезшкірного коронарного втручання, виявило здатність простих гемодинамічних параметрів, отриманих під час катетеризації серця, прогнозувати внутрішньогоспітальну смертність після інфраркту міокарда з підйомом ST. Ретроспективне одноцентрове дослідження включало 219 пацієнтів з ІМ, яким після успішної реваскуляризації було виміряно кінцевий діастолічний тиск лівого шлуночка, систолічний артеріальний тиск і діастолічний артеріальний тиск аорти. Коефіцієнт САТ/ДТЛШ порівнювали з основними показниками ризику смертності. Було встановлено, що пацієнти із САТ/ДТЛШ $\leq 4$ мали підви- 
щений ризик смерті в стаціонарі (32,0 проти $5,3 \%, \mathrm{P}<0,0001)$, вищу частоту застосування внутрішньоаортального балонного насоса (51,6 проти 9,6 \%, P<0,0001) і комбіновану кінцеву точку смерті або використання цього насоса (58,1 проти 13,3 \%, Р<0,0001) порівняно 3 хворими із САТ/ДТЛШ >4. Специфрічність та прогностична цінність позитивного результату коефріцієнта САТ/ДТЛШ для стаціонарної смертності (площа під ROC-кривою - 0,69) були достовірно вищими, ніж ДТЛШ $(0,61, \mathrm{P}=0,04)$ або пульсовий тиск $(0,55, P=0,02)$, але подібними до Shock Index (співвідношення частоти серцевих скорочень до CAT) і Modified Shock Index (співвідношення частоти серцевих скорочень до середнього артеріального тиску).

ще одне подібне дослідження німецьких учених [23] визначало прогностичну цінність співвідношення фрракції викиду лівого шлуночка до кінцевого діастолічного тиску лівого шлуночка (ФВЛШ/ДТЛШ) у 1283 пацієнтів з IM, які пройшли первинну коронарну інтервенцію. Співвідношення ФВЛШ/ДТЛШ, на відміну від тільки ФВЛШ або ДТЛШ, покращувало прогнозованість багатоваріантних моделей щодо довгострокової серцевої смертності в пацієнтів з IM, які пройшли первинну коронарну інтервенцію, - більш низьке співвідношення ФВЛШ/ДТЛШ було незалежно пов'язане з підвищеним ризиком серцевої смертності до 8-ми років після первинної коронарної інтервенції.

Враховуючи великий потенціал пошуку інформативних шкал ризику ССП, які базуються на простих клінічних параметрах, наступним кроком нашого дослідження було оцінити загальноприйняті калькулятори ризику у хворих на IM з КП залежно від рівнів АТ. Спочатку ми проаналізували взаємозв'язки між САТ/ДАТ у гострий період інфраркту міокарда та високим ступенем ризику ССП за шкалою GRACE, а також високоступеневою $\mathrm{CH}$ за NYHA (табл. 4).

У результаті обчислень не було виявлено достовірної кореляції між рівнями АТ у гострий період IM та високим ступенем ризику ССП за шкалою GRACE. Натомість в осіб із вираженою $\mathrm{CH}$ (III-IVФК) рання реакція як систолічного, так і діастолічного артеріального тиску була достовірно менш вираженою, ніж у хворих з нижчим функціональним класом за NYHA. Таку ж тенденцію підтвердило і вивчення залежності рівнів АТ від показників фрракції викиду лівого шлуночка за даними ехокардіоскопії: найменші значення ФВЛШ виявляли саме в пацієнтів з найнижчими показниками систолічного та діастолічного артеріального тиску (табл. 5).

Аналіз зв'язків ступеня ризику ССП та рівнів AT у гострий період IM ні за шкалою GRACE, ні за шкалою ризику АНА не виявив достовірної кореляції. Нечутливою до зміни рівнів АТ виявилася і градація пацієнтів на фрункціональні класи за реабілітаційною класифрікацією, тому їх недоцільно використовувати як скринінгові стратифрікаційні шкали для розподілу коморбідних хворих у реабілітаційні програми.

Враховуючи суттєву залежність фуннкціонального стану хворих на IM від наявності супутньої коморбідної патології та персистувальних ускладнень у госпітальний період інораркту міокарда, доцільно було дослідити стан функціональних резервів та толерантність до фрізичного навантаження для визначення критеріїв призначення тієї чи іншої програми реабілітації.

Таблиця 4 - Залежність рівнів артеріального тиску в гострий період інфраркту міокарда від ступеня серцевої недостатності та ризику серцево-судинних подій за шкалою GRACE

\begin{tabular}{|c|c|c|c|c|c|c|c|c|}
\hline \multirow[b]{2}{*}{$\begin{array}{l}\text { Клінічний } \\
\text { показник }\end{array}$} & \multicolumn{4}{|c|}{ CAT } & \multicolumn{4}{|c|}{ ДАТ } \\
\hline & $\begin{array}{c}\text { ступінь } \\
\text { СН за } \\
\text { NYHA - } \\
\text { 1-2 бали }\end{array}$ & $\begin{array}{c}\text { ступінь } \\
\text { СН за } \\
\text { NYHA - } \\
\text { 3-4 бали }\end{array}$ & $\begin{array}{c}\text { ризик за } \\
\text { шкалою } \\
\text { GRACE - } \\
2 \text { бали }\end{array}$ & $\begin{array}{c}\text { ризик за } \\
\text { шкалою } \\
\text { GRACE - } \\
3 \text { бали }\end{array}$ & $\begin{array}{c}\text { ступінь } \\
\text { СН за } \\
\text { NYHA - } \\
\text { 1-2 бали }\end{array}$ & $\begin{array}{c}\text { ступінь } \\
\text { СН за } \\
\text { NYHA - } \\
\text { 3-4 бали }\end{array}$ & $\begin{array}{c}\text { ризик за } \\
\text { шкалою } \\
\text { GRACE - } \\
2 \text { бали }\end{array}$ & $\begin{array}{c}\text { ризик за } \\
\text { шкалою } \\
\text { GRACE - } \\
3 \text { бали }\end{array}$ \\
\hline $\begin{array}{l}\text { Середнє } \\
\text { значення }\end{array}$ & 140,042 & 130,532 & 135,385 & 129 & 84,958 & 80,893 & 83,846 & 78,253 \\
\hline Кількість осіб & 119 & 252 & 26 & 166 & 119 & 252 & 26 & 166 \\
\hline $\begin{array}{l}\text { Загальна } \\
\text { кількість осіб }\end{array}$ & \multicolumn{2}{|c|}{371} & \multicolumn{2}{|c|}{192} & \multicolumn{2}{|c|}{371} & \multicolumn{2}{|c|}{192} \\
\hline Частка & 0,321 & 0,679 & 0,135 & 0,865 & 0,321 & 0,679 & 0,135 & 0,865 \\
\hline $\begin{array}{l}\text { Стандартне } \\
\text { відхилення }\end{array}$ & \multicolumn{2}{|c|}{30,174} & \multicolumn{2}{|c|}{35,285} & \multicolumn{2}{|c|}{15,874} & \multicolumn{2}{|c|}{18,264} \\
\hline $\begin{array}{l}\text { Точково- } \\
\text { бісерійна } \\
\text { кореляція }\end{array}$ & \multicolumn{2}{|c|}{$-0,147$} & \multicolumn{2}{|c|}{$-0,062$} & \multicolumn{2}{|c|}{$-0,120$} & \multicolumn{2}{|c|}{$-0,105$} \\
\hline $\begin{array}{l}\text { Т-критерій } \\
\text { у квадраті }\end{array}$ & \multicolumn{2}{|c|}{8,186} & \multicolumn{2}{|c|}{0,735} & \multicolumn{2}{|c|}{5,363} & \multicolumn{2}{|c|}{2,121} \\
\hline Р-значення & \multicolumn{2}{|c|}{0,004} & \multicolumn{2}{|c|}{0,392} & \multicolumn{2}{|c|}{0,021} & \multicolumn{2}{|c|}{0,147} \\
\hline
\end{tabular}


Таблиця 5 - Дисперсійний аналіз (ANOVA) залежності рівнів систолічного та діастолічного артеріального тиску в гострий період інфаркту міокарда від ступеня систолічної дисфункції лівого шлуночка за даними ехокардіоскопії

\begin{tabular}{|l|c|c|c|}
\hline \multicolumn{1}{|c|}{ Показник } & Кількість спостережень & САТ $(\mathrm{M} \pm \mathrm{SD})$ & ДАТ (M $\pm \mathrm{SD})$ \\
\hline ФВ $>55 \%$ & 18 & $134,444 \pm 32,580$ & $77,778 \pm 10,603$ \\
\hline ФВ $=45-55 \%$ & 62 & $142,097 \pm 39,219$ & $83,226 \pm 17,927$ \\
\hline ФВ=30-45\% & 68 & $124,323 \pm 26,617$ & $78,236 \pm 15,496$ \\
\hline ФВ<30\% & 8 & $82,500 \pm 52,576$ & $55,000 \pm 35,857$ \\
\hline Усього & 156 & $130,410 \pm 36,662$ & $78,974 \pm 18,384$ \\
\hline (F-статистика) & 8,405 & 6,286 \\
\hline \multicolumn{2}{|r|}{} & 0,142 & 0,110 \\
\hline Р-значення & $<0,0001$ & $<0,001$ \\
\hline
\end{tabular}

У результаті вивчення залежності "золотого стандарту" оцінки толерантності до фрізичного навантаження (тесту шестихвилинної ходьби) від рівнів артеріального тиску в гострий період ІМ встановлено, що САТ та ДАТ перебувають у прямій кореляції з відстанню, яку пройшли пацієнти за 6 хв, на 10-й, 30-й і 90-й дні реабілітації. Зв'язок виявився сильним і для ТШХ ${ }_{10}$, який характеризує стаціонарний етап реабілітації, достовірним (табл. 6).

На амбулаторному етапі спостерігали різну чутливість ТШХ. Так, на ранньому амбулатор- ному етапі (ТШХ ${ }_{30}$ ) прогностичним маркером кращої фрункціональної здатності виявився САТ, а на пізньому амбулаторному етапі (TШХ $\left.{ }_{90}\right)$ вищі рівні ДАТ при госпіталізації мали достовірну позитивну кореляцію з вищими показниками шестихвилинного тесту. Отримані дані свідчать про вищі можливості відновлення толерантності до фрізичного навантаження в тих післяінфрарктних хворих із КП, які реагували підвищенням САТ і ДАТ у гострий період ІМ, причому ця залежність $€$ актуальною як для стаціонарного, так і для амбулаторного етапів реабілітації.

Таблиця 6 - Залежність тесту шестихвилинної ходьби на 10-й, 30-й та 90-й дні реабілітації від рівнів артеріального тиску в гострий період інфраркту міокарда

\begin{tabular}{|l|c|c|c|c|c|c|}
\hline \multirow{2}{*}{ Клінічний показник } & \multicolumn{3}{|c|}{ САТ на 1-шу добу IM } & \multicolumn{3}{c|}{ ДАТ на 1-шу добу IM } \\
\cline { 2 - 7 } & $\mathrm{TWX}_{10}$ & $\mathrm{TWX}_{30}$ & $\mathrm{TWX}_{90}$ & $\mathrm{TWX}_{10}$ & $\mathrm{TWX}_{30}$ & $\mathrm{TWX}_{90}$ \\
\hline Кореляція & 0,179 & 0,173 & 0,088 & 0,153 & 0,129 & 0,205 \\
\hline Т-критерій & 2,477 & 2,395 & 1,161 & 2,029 & 1,722 & 2,741 \\
\hline Р-значення & 0,014 & 0,018 & 0,247 & 0,044 & 0,087 & 0,007 \\
\hline
\end{tabular}

Примітка. ТШХ - тест шестихвилинної ходьби; ТШХ день від початку розвитку IM; ТШХ ${ }_{30}$ - значення тесту шестихвилинної ходьби, проведеного на 30-й день від початку розвитку IM; ТШХ

ВИСНОВКИ. 1. Показники САТ/ДАТ у гострий період інораркту міокарда є ранніми прогностичними маркерами біохімічних, морорологічних та гемодинамічних змін у хворих на інораркт міокарда з коморбідною патологією, адекватно відображають загальний функціональний стан пацієнта та серцево-судинні ризики, тому їх необхідно моніторувати в процесі реабілітації.

2. Низькі рівні систолічного та діастолічного артеріального тиску в гострий період інфаркту міокарда свідчать про виснаження гемодинамічної компенсації систолічної фуункції серцевого м'яза, і їх можна розглядати як лімітуючі маркери для проведення ранньої активації коморбідного пацієнта.
3. Рівень креатиніну у хворих на інфраркт міокарда з коморбідною патологією має прямий достовірний зв'язок з показниками діастолічного артеріального тиску в його гострий період та морорологічними змінами серцевого м'яза, тому може успішно використовуватись як маркер системного гемодинамічного контролю на етапах кардіореабілітації.

Перспективи подальших досліджень. Доцільно продовжити вивчення показників функціонального стану хворих на інфраркт міокарда 3 коморбідною патологією як можливих маркерів і лімітуючих фракторів реабілітаційного процесу з оцінкою їх специфрічності та прогностичної цінності. 


\section{СПИСОК ЛІТЕРАТУРИ}

1. World Health Organization: WHO. URL : https:// www.who.int/ru/news-room/fact-sheets/detail/cardiovascular-diseases-(cvds)

2. Heart disease and stroke statistics-2016 update: a report from the American Heart Association / D. Mozaffarian, E. J. Benjamin, A. S. Go [et al.] // Circulation. 2016. - 133 (4). - P. e38-e360.

3. Townsend Nichols N. Cardiovascular disease in Europe - epidemiological update / Townsend N. Nichols, M. Scarborough, P. Rayner M. // Eur. Heart J. - 2015. 36. - P. 2696-2705.

4. Поширеність фракторів ризику серцево-судинних захворювань в Україні: сучасний погляд на проблему [Електронний ресурс] / Д. Д. Дячук, Г.З.Мороз, І. М. Гідзинська, Т. С. Ласиця // Укр. кардіол. журн. 2018. - № 1. - С. 91-101. - Режим доступу : http:// journal.ukrcardio.org/wp-content/uploads/2018/01/ 10_1_2018.pdf.

5. Hypertension and acute myocardial infarction : an overview / R. Pedrinelli, P. Ballo, C. Fiorentini [et al.] // J. Cardiovasc. Med. (Hagerstown). - 2012. - No. 13 (3). P. 194-202. doi:10.2459/JCM.0b013e3283511ee2. URL: https://www.ncbi.nlm.nih.gov/pubmed/22317927

6. Multimorbidity and survival for patients with acute myocardial infarction in England and Wales: Latent class analysis of a nationwide population-based cohort $/$ M. Hall, T. B. Dondo, A. T. Yan [et al.] // PLoS Med. 2018. - No. 15 (3). - P. e1002501. doi: 10.1371/journal. pmed.1002501.

7. 2017 ESC Guidelines for the management of acute myocardial infarction in patients presenting with STsegment elevation: The Task Force for the management of acute myocardial infarction in patients presenting with ST-segment elevation of the European Society of Cardiology (ESC) / B. Ibanez, S. James, S. Agewall [et al.] // European Heart Journal. - 2018. - 39, Issue 2. - P. 119177. - URL : https://doi.org/10.1093/eurheartj/ehx393

8. 2015 ESC Guidelines for the management of acute coronary syndromes in patients presenting without persistent ST-segment elevation : Task Force for the Management of Acute Coronary Syndromes in Patients Presenting without Persistent ST-Segment Elevation of the European Society of Cardiology (ESC) / M. Roffi, C. Patrono, J. Ph. Collet [et al.]//European Heart Journal. 37, Issue 3. - P. 14. - URL : https://doi.org/10.1093/ eurheartj/ehv320

9. Гострий коронарний синдром без елевації сегмента ST : унісрікований клінічний протокол екстреної, первинної, вторинної, третинної медичної допомоги та медичної реабілітації [Електронний ресурс]. - Режим доступу : http://www.webcardio.org/unifikovanyjklinichnyj-protokol-ekstrenoji-pervynnoji-vtorynnojitretynnoji-medychnoji-dopomoghy-ta-medychnojireabilitatsiji-ghostryj-koronarnyj-syndrom-bez-elevatsijiseghmenta-st.aspx.

10. Charlson M. E. A new method of classifying prognostic comorbidity in longitudinal studies: Development and validation / M. E. Charlson, P. Pompei, H. L. Ales // Journal Chronic Disease. - 1987. - 40. P. 373-383.

11. Швед М. І. Підходи до оцінки ризиків та фрункціональних резервів серцево-судинної системи у хворих на інфраркт міокарда з коморбідною патологією, які перебувають у гострому періоді кардіореабілітації /
М. І. Швед, Л. В. Левицька // Світ медицини та біолоriï. - 2018. - № 4 (66). - С. 124-130.

12. Repeated six-minute walk tests for outcome measurement and exercise prescription in outpatient cardiac rehabilitation: a longitudinal study / R. N. Bellet, R. Francis, J. S. Jacob [et al.] // Arch. Phys. Med. Rehabil. - 2011. - 92 (9). - P. 1388-1394.

13. Уткин В. А. Методические аспекты математико-статистического анализа медицинских данных. Часть 2. Атрибутивная статистика в медицинских исследованиях / В. А. Уткин // Мед. вестн. Северного Кавказа. - 2009. - № 3 (15). - С. 70-75.

14. Pett M. A. Nonparametric statistics for health care research: Statistics for small samples and unusual distributions / M. A. Pett. - Thousand Oaks; 1997. - CA: Sage Publications.

15. An effective indicator in predicting cardiovascular events: urine albumin to creatinine ratio / $\mathrm{H}$. Zhao, Y. F. Jiang, X. C. Zhou [et al.] // Eur. Rev. Med. Pharmacol. Sci. - 2017. - No. 21 (14). - P. 3290-3295.

16. Impact of co-morbid burden on mortality in patients with coronary heart disease, heart failure and cerebrovascular accident: a systematic review and metaanalysis / M. Rashid, C. S. Kwok, C. P. Gale [et al.] // Eur. Heart J. Qual. Care Clin. Outcomes. -2017. - No. 3 (1). P. 20-36.

17. Epidemiology of multimorbidity and implications for health care, research, and medical education: a crosssectional study / K. Barnett, S. W. Mercer, M. Norbury [et al.] // Lancet. - 2012. - 380 (9836). - P. 37-43.

18. Cardioreabilitation peculiarities and correction of violations of systolic, diastolic function and heart rate variability in patients with acute coronary syndrome and coronary / M. Shved, L. Tsuglevych, I. Kyrychok [et al.] // Georgian Medical News. - P. 46-53.

19. Systolic and diastolic blood pressure changes in relation with myocardial infarction and stroke in patients with coronary artery disease / P. Verdecchia, G. Reboldi, F. Angeli [et al.] // Hypertension. - 2015. - No. 65 (1). P. 108-114. doi: 10.1161/HYPERTENSIONAHA.114.04310.

20. Admission blood pressure and 1-year mortality in acute myocardial infarction / D. Roth, R. Van Tulder, B. Heidinger [et al.] // Int. J. Clin. Pract. -2015. - 69 (8). P. 812-819. doi:10.1111/ijcp.12588.

21. Association between mean systolic and diastolic blood pressure throughout the follow-up and cardiovascular events in acute myocardial infarction patients with systolic dysfunction and/or heart failure: an analysis from the High-Risk Myocardial Infarction Database Initiative / J. P. Ferreira, K. Duarte, M. A. Pfeffer [et al.] // Eur. J. Heart Fail. -2018. - 20 (2). - P. 323-331. doi: 10.1002/ejhf.1131

22. Ratio of systolic blood pressure to left ventricular end-diastolic pressure at the time of primary percutaneous coronary intervention predicts in-hospital mortality in patients with ST-elevation myocardial infarction / M. Sola, K. Venkatesh, M. Caughey [et al.] // Catheter Cardiovasc. Interv. -2017. -90 (3). -P. 389-395. doi:10.1002/ccd.26963.

23. Relation of ratio of left ventricular ejection fraction to left ventricular end-diastolic pressure to long-term prognosis after ST-segment elevation acute myocardial infarction / G. Ndrepepa, S. Cassese, M. Emmer [et al.] // The American Journal of Cardiology. -2018. - 123 (2). P. 199-205. DOI: 10.1016/j.amjcard.2018.10.007. 


\section{REFERENCES}

1. World Health Organization: WHO. Retrieved from: https://www.who.int/ru/news-room/fact-sheets/detail/ cardiovascular-diseases-(cvds).

2. Mozaffarian, D., Benjamin, E.J., Go, A.S., Arnett, D.K., Blaha, M.J., \& Cushman, M. (2016). Heart disease and stroke statistics-2016 update: a report from the American Heart Association. Circulation, 133 (4), e38-e360.

3. Townsend, N., Nichols, M. Scarborough, P. \& Rayner, M. (2015). Cardiovascular disease in Europe epidemiological update 2015. Eur. Heart J., 36, 26962705.

4. Diachuk, D.D., Moroz, H.Z., Hidzynska, I.M., \& Lasytsia, T.S. (2018). Poshyrenist faktoriv ryzyku sertsevo-sudynnykh zakhvoriuvan v Ukraini: suchasnyi pohliad na problemu [Prevalence of risk factors for cardiovascular diseases in Ukraine: a modern view of the problem]. Ukrainskyi kardiolohichnyi zhurnal - Ukrainian Cardiology Journal, 1, 91-101. Retrieved from: http:// journal.ukrcardio.org/wp-content/uploads/2018/01/ 10_1_2018.pdf [in Ukrainian].

5. Pedrinelli, R., Ballo, P., Fiorentini, C., Denti, S., Galderisi, M., Ganau, A., ... \& Zacà, V. (2012). Hypertension and acute myocardial infarction: an overview. J. Cardiovasc. Med. (Hagerstown), 13 (3), 194-202. Retrieved from: https://www.ncbi.nlm.nih.gov/pubmed/ 22317927. doi:10.2459/JCM.0b013e3283511ee2.

6. Hall, M., Dondo, T.B., Yan, A.T., Mamas, M.A., Timmis, A.D., Deanfield, J.E., ... \& Gale, C.P. (2018). Multimorbidity and survival for patients with acute myocardial infarction in England and Wales: Latent class analysis of a nationwide population-based cohort. PLOS Med., 15 (3), e1002501. doi:10.1371/journal.pmed.1002501.

7. Ibanez, B., James, S., Agewall, S., Antunes, M.J., Bucciarelli-Ducci, C., Bueno, H., ... \& Goudevenos, J.A. (2018). 2017 ESC Guidelines for the management of acute myocardial infarction in patients presenting with ST-segment elevation: The Task Force for the management of acute myocardial infarction in patients presenting with ST-segment elevation of the European Society of Cardiology (ESC). European Heart Journal, 39, 2, 119177. Retrieved from: https://doi.org/10.1093/eurheartj/ ehx393

8. Roffi, M., Patrono, C., Collet, J.-Ph., Mueller, Ch., Valgimigli, M., Andreotti, F., ... \& Chew, D.P. (2016). 2015 ESC Guidelines for the management of acute coronary syndromes in patients presenting without persistent STsegment elevation: Task Force for the Management of Acute Coronary Syndromes in Patients Presenting without Persistent ST-Segment Elevation of the European Society of Cardiology (ESC). European Heart Journal, 37, 3, 267-315. Retrieved from: https://doi.org/10.1093/ eurheartj/ehv320

9. Hostryi koronarnyi syndrom bez elevatsii sehmenta ST: unifikovanyi klinichnyi protokol ekstrenoi, pervynnoi, vtorynnoi, tretynnoi medychnoi dopomohy ta medychnoi reabilitatsii [Acute coronary syndrome without ST segment elevation: unified clinical protocol for emergency, primary, secondary, tertiary care and medical rehabilitation]. Retrieved from: http://www.webcardio.org/ unifikovanyj-klinichnyj-protokol-ekstrenoji-pervynnojivtorynnoji-tretynnoji-medychnoji-dopomoghy-tamedychnoji-reabilitatsiji-ghostryj-koronarnyj-syndrombez-elevatsiji-seghmenta-st.aspx
10. Charlson, M.E., Pompei, P., \& Ales, H.L. (1987). A new method of classifying prognostic comorbidity in longitudinal studies: Development and validation. Journal Chronic Disease, 40, 373-383.

11. Shved, M.I., \& Levytska, L.V. (2018). Pidkhody do otsinky ryzykiv ta funktsionalnykh rezerviv sertsevosudynnoi systemy u khvorykh na infarkt miokarda z komorbidnoiu patolohiieiu, yaki perebuvaiut u hostromu periodi kardioreabilitatsii [Approaches to the assessment of the risks and functional reserves of the cardiovascular system in patients with myocardial infarction with comorbid pathology, who are in the acute period of cardio-rehabilitation]. Svit medytsyny ta biolohii - World of Medicine and Biology, 4 (66), 124-130 [in Ukrainian].

12. Bellet, R.N., Francis, R., Jacob, J.S., Healy, K.M., Bartlett, H.J., Adams, H.J., \& Morris, M. (2011). Repeated six-minute walk tests for outcome measurement and exercise prescription in outpatient cardiac rehabilitation: a longitudinal study. Arch. Phys. Med. Rehabil., 92 (9), 1388-1394.

13. Utkin, V.A. (2009). Metodicheskiie aspekty matematiko-statisticheskogo analiza meditsinskikh dannykh. Chast 2. Atributivnaya statistika v meditsinskikh issledovaniyakh [Methodological aspects of the mathematical-statistical analysis of medical data Part 2. Attributive statistics in medical research]. Meditsinskiy vestnik Severnogo Kavkaza - Medical Journal of the North Caucasus, 3 (15), 70-75.

14. Pett, M.A. (1997). Nonparametric statistics for health care research: Statistics for small samples and unusual distributions. Thousand Oaks. CA: Sage Publications.

15. Zhao, H., Jiang, Y.F., Zhou, X.C., Yao, L., Chen, J., Wang, D., \& Fu, D.Y. (2017). An effective indicator in predicting cardiovascular events: urine albumin to creatinine ratio. Eur. Rev. Med. Pharmacol. Sci., 21 (14), 3290-3295.

16. Rashid, M., Kwok, C.S., Gale, C.P., Doherty, P., Olier, I., \& Sperrin, M. (2017). Impact of co-morbid burden on mortality in patients with coronary heart disease, heart failure and cerebrovascular accident: a systematic review and meta-analysis. Eur. Heart J. Qual. Care Clin. Outcomes, 3 (1), 20-36.

17. Barnett, K., Mercer, S.W., Norbury, M., Watt, G., Wyke, S., \& Guthrie, B. (2012). Epidemiology of multimorbidity and implications for health care, research, and medical education: a cross-sectional study. Lancet, 380 (9836), 37-43.

18. Shved, M., Tsuglevych, L., Kyrychok, I., Levytska, L., Boiko, T., \& Kitsak, Y. (2017). Cardio-rehabilitation peculiarities and correction of violations of systolic, diastolic function and heart rate variability in patients with acute coronary syndrome and coronary artery revascularization. Georgian Medical News, 265, 46-53.

19. Verdecchia, P., Reboldi, G., Angeli, F., Trimarco, B., Mancia, G., Pogue, J., ... \& Yusuf, S. (2015). Systolic and diastolic blood pressure changes in relation with myocardial infarction and stroke in patients with coronary artery disease. Hypertension, 65 (1), 108-114. doi: 10.1161/HYPERTENSIONAHA.114.04310.

20. Roth, D., Van Tulder, R., Heidinger, B., Herkner, H., Schreiber, W., \& Havel, C. (2015). Admission blood pressure and 1-year mortality in acute myocardial infarction. Int. J. Clin. Pract., 69 (8), 812-819. doi:10.1111/ijcp.12588. 
21. Ferreira, J.P., Duarte, K., Pfeffer, M.A., McMurray, J.J.V., Pitt, B., Dickstein, K., ... \& Rossignol, P. (2018). Association between mean systolic and diastolic blood pressure throughout the follow-up and cardiovascular events in acute myocardial infarction patients with systolic dysfunction and/or heart failure: an analysis from the High-Risk Myocardial Infarction Database Initiative. Eur. J. Heart Fail, 20 (2), 323-331. doi: 10.1002/ejhf.1131.

22. Sola, M., Venkatesh, K., Caughey, M., Rayson, R., Dai, X., Stouffer, G.A., \& Yeung, M. (2017). Ratio of systolic blood pressure to left ventricular end-dia- stolic pressure at the time of primary percutaneous coronary intervention predicts in-hospital mortality in patients with ST-elevation myocardial infarction. Catheter Cardiovasc. Interv., 90 (3), 389-395. doi:10.1002/ ccd.26963.

23. Ndrepepa, G., Cassese, S., Emmer, M., Mayer, K., Kufner, S., Xhepa, E., ... \& Kastrati, A. (2018). Relation of ratio of left ventricular ejection fraction to left ventricular end-diastolic pressure to long-term prognosis after ST-segment elevation acute myocardial infarction. The American Journal of Cardiology, 123 (2), 199-205. DOI: 10.1016/j.amjcard.2018.10.007.

Л. В. Левицкая

ТЕРНОПОЛЬСКИЙ ГОСУДАРСТВЕННЫЙ МЕДИЦИНСКИЙ УНИВЕРСИТЕТ ИМЕНИ И. Я. ГОРБАЧЕВСКОГО

\section{КОНСТЕЛЛЯЦИИ БИОХИМИЧЕСКИХ И ФИЗИЧЕСКИХ МАРКЕРОВ ФУНКЦИОНАЛЬНОГО СОСТОЯНИЯ ОРГАНИЗМА БОЛЬНЫХ ИНФАРКТОМ МИОКАРДА С УРОВНЯМИ СИСТОЛИЧЕСКОГО И ДИАСТОЛИЧЕСКОГО АРТЕРИАЛЬНОГО ДАВЛЕНИЯ И ВОЗМОЖНОСТЬ ИХ ИСПОЛЬЗОВАНИЯ В ПРОЦЕССЕ РЕАБИЛИТАЦИИ}

\section{Резюме}

Вступление. Предоставление полноценной медицинской помощи больным инфрарктом миокарда (ИМ) с коморбидной патологией (КП) на фроне артериальной гипертензии остается сложной медицинской проблемой, которая на сегодняшний день не решена.

Цель исследования - изучить особенности клинического течения инфраркта миокарда с коморбидной патологией в зависимости от уровней систолического и диастолического артериального давления, выявить ранние маркерные и лимитирующие параметры ффункциональных показателей организма и стратифрикационные риски для контроля за эффрективностью реабилитационного процесса в этой категории пациентов.

Методы исследования. Обследовано 371 больного инфрарктом миокарда в возрасте $(66,2 \pm 10,4)$ года. В 93,8 \% обследованных было выявлено сопутствующую патологию. Изучены основные фуннциональные показатели состояния организма больного ИМ с КП и их связь с систолическим (САД) и диастолическим артериальным давлением (ДАД), а также с показателями толерантности к фризической нагрузке.

Результаты и обсуждение. Было установлено прямую корреляцию между уровнями САД в острый период Им и продолжительностью анамнеза артериальной гипертензии ( $r=0,130 ; P=0,040)$, толщиной задней стенки левого желудочка $(r=0,189 ; P<0,001)$, фрракцией выброса левого желудочка $(r=0,275 ; P<0,0001)$ и размером аорты (r=0,228; $P<0,0001)$. Существовала также достоверная прямая связь между уровнями ДАД и толщиной задней стенки левого желудочка ( $r=0,130 ; P=0,022)$, размером аорты $(r=0,172 ; P=0,002)$, размером левого предсердия ( $r=0,188 ; P=0,001)$, фрракцией выброса левого желудочка $(r=0,210 ; P<0,001), a$ также уровнем креатинина крови ( $r=0,119 ; P=0,023)$. Обнаруженная достоверная обратная связь между уровнями САД/ДАД и пароксизмом фрибрилляции предсердий, кардиогенным шоком, отеком легких и аневризмой левого желудочка может свидетельствовать об истощении гемодинамических резервов, пониженных вследствие острого ишемического повреждения миокарда.

Выводы. Показатели САД/ДАД в острый период ИМ являются ранними прогностическими маркерами биохимических, морорологических и гемодинамических изменений у больных Им с КП, адекватно отражают общее ффункциональное состояние пациента и сердечно-сосудистые риски, поэтому их необходимо мониторить в процессе реабилитации. Существует достоверная прямая связь уровня креатинина у таких пациентов с показателями ДАД в острый период Им и морфологическими изменениями сердечной мышцы, поэтому его можно успешно использовать как маркер системного гемодинамического контроля на этапах кардиореабилитации.

КЛЮЧЕВЫЕ СЛОВА: инфаркт миокарда; коморбидная патология; артериальная гипертензия; кардиореабилитация. 


\section{CONSTELLATION OF BIOCHEMICAL AND PHYSICAL MARKERS OF THE FUNCTIONAL STATE OF THE BODY IN PATIENTS WITH MYOCARDIAL INFARCTION WITH SYSTOLIC AND DIASTOLIC BLOOD PRESSURE LEVELS AND THE POSSIBILITY OF THEIR USING IN THE REHABILITATION PROCESS}

\section{Summary}

Introduction. Providing full medical care to patients with myocardial infarction (MI) with comorbid pathology $(C P)$ on the background of arterial hypertension remains a complicated medical problem, which has not been resolved to date.

The aim of the study - to learn the peculiarities of the clinical course of myocardial infarction with comorbid pathology depending on the levels of systolic and diastolic blood pressure, to identify the early marker and limiting parameters of the functional parameters of the body and stratification risks to control the effectiveness of the rehabilitation process in this category of patients.

Research Methods. We examined 371 patients with myocardial infarction aged (66.2 \pm 10.4$)$ years. In $93.8 \%$ of the surveyed, concomitant pathology was detected. The basic functional indicators of a patient's body condition on the MI with CP and their relationship with SBP and DBP, as well as indicators of physical activity tolerance were studied.

Results and Discussion. There was a direct correlation between the levels of SBP in the acute MI period and the duration of the history of arterial hypertension $(r=0.130 ; P=0.040)$; left ventricular posterior wall thickness $(r=0.189$; $P<0.001)$; left ventricular ejection fraction $(r=0.275 ; P<0.0001)$ and the size of aorta $(r=0.228 ; P<0.0001)$. There was also a direct relationship between the levels of $D B P$ and the left ventricular posterior wall thickness $(r=0.130 ; P=0.022)$; the size of the aorta $(r=0.172 ; P=0.002)$; the size of the left atrium $(r=0.188 ; P=0.001)$, left ventricular ejection fraction $(r=0,210 ; P<0,001)$, as well as blood creatinine levels $(r=0,119 ; P=0,023)$. Authentic feedback between SBP/DBP levels and paroxysmal atrial fibrillation, cardiogenic shock, pulmonary edema, and left ventricular aneurysm may indicate a depletion of hemodynamic reserves reduced due to acute ischemic damage to the myocardium.

Conclusions. SBP/DBP indicators in the acute MI period are early prognostic markers of biochemical, morphological and hemodynamic changes in patients with MI with CP, adequately reflect the overall functional state of the patient and cardiovascular risks, and therefore they should be monitored during the rehabilitation process. There is a significant direct correlation between creatinine levels in such patients with DBP in acute MI and morphological changes in the cardiac muscle, so it can be successfully used as a marker for systemic hemodynamic control at the stages of cardio-rehabilitation.

KEY WORDS: myocardial infarction; comorbid pathology; arterial hypertension; cardio-rehabilitation.

Отримано 17.01.2019

Адреса для листування: Л. В. Левицька, Тернопільський державний медичний університет імені І. Я. Горбачевського, майдан Волі, 1, Тернопіль, 46001, Україна, e-mail: larlev752@gmail.com. 